\title{
IL-16 rs4778889 polymorphism contribution to the development of renal cell cancer in a Chinese population
}

\author{
S.X. Yang, F. Chen, J.W. Zhang, Z.Q. Sun and B.P. Chen \\ Department of Nephrology, Huaihe Hospital of Henan University, Kaifeng, \\ Henan, China \\ Corresponding author: B.P. Chen \\ E-mail: yangssxia@163.com \\ Genet. Mol. Res. 15 (2): gmr.15027553 \\ Received August 31, 2015 \\ Accepted December 22, 2016 \\ Published June 10, 2016 \\ DOI http://dx.doi.org/10.4238/gmr.15027553
}

\begin{abstract}
IL-16 plays an important role in affect the secretion of tumor-related inflammatory cytokines. We aimed to assess the role of interleukin-16 (IL-16) rs4778889 T/C and rs11556218 T/G polymorphisms in the occurrence of renal cell cancer (RCC). This study is composed of 274 RCC patients and 274 control subjects. Genotyping of polymorphisms was performed using polymerase chain reaction combined with restriction fragment length polymorphism analysis. All statistical analysis was carried out by the SPSS statistical software package, version 16.0 (SPSS Inc., Chicago, IL, USA). Using conditional logistic regression analysis, the TC and $\mathrm{CC}$ genotypes of rs4778889 exhibited a higher risk of RCC, with adjusted ORs (and 95\%CIs) of 1.79 (1.23-2.62) and 2.67 (1.29-5.69), respectively. Moreover, under dominant and recessive models, individuals carried the rs4778889 polymorphism was exhibited elevated RCC risk, with adjusted ORs (and 95\%CI) of 1.93 (1.35-2.76) and 2.11 (1.05-4.45), respectively. No significant differences were observed in rs11556218 genotype frequencies between the study groups. In conclusion, the
\end{abstract}


results of our study reveal an association between the $I L-16$ rs4778889 polymorphism and heightened risk of RCC.

Key words: $I L-16$; Polymorphism; Renal cell cancer

\section{INTRODUCTION}

The complex trait disease renal cell cancer (RCC) accounts for more than $90 \%$ of all renal malignancies (Chow et al., 2010). The incidence of RCC shows variation among different populations, which shows higher in Europeans and lower in Asians (Chow et al., 2010). The etiology of RCC is not well-understood. The pathogenesis of RCC is caused by many complex environmental and lifestyle factors, such as obesity, diabetes, hypertension, tobacco smoking, alcohol consumption, and family history (Vineis et al., 2004; Adams et al., 2008; Chow et al., 2010; Bellocco et al., 2012). Currently studies have suggested that the tumorigenesis of renal cell cancer involves complex process determined by the interactions between environmental and genetic factors (Semenza et al., 2001). It also has been suggested that many genetic elements may contribute to the occurrence of this cancer, such as DNA repair genes, cytochrome P450 family 3 subfamily A member 5 gene (CYP3A5), ATP binding cassette subfamily B member 1 gene (ABCB1), interleukin-27 (IL-27) gene, pre-miR-146a gene and vascular endothelial growth factor (VEGF) gene (Diekstra et al., 2015; Huang et al., 2015; Xian et al., 2015).

Molecular mechanisms underlying inflammation-associated cancer included DNA damage, disruption of the immune response and alternation of the tumor microenvironment, which were associated with disequilibrium of inflammatory cytokines. It is reported that IL16 plays an important role in affect the secretion of tumor -related inflammatory cytokines (Muc-Wierzgon et al., 2006; Shanmugham et al., 2006). Two common polymorphisms in $I L$ 16 (rs4778889 T/C and rs $11556218 \mathrm{~T} / \mathrm{G}$ ) have been found to be associated with inflammatory diseases, such as late-onset Alzheier's disease, knee osteoarthritis, graves' disease and endometriosis (Gan et al., 2010; Tsai et al., 2014; Anvar et al., 2015; Luo et al., 2015). Therefore, we conducted a hospital-based case-control study to evaluate the association between $I L-16$ rs4778889 T/C and rs $11556218 \mathrm{~T} / \mathrm{G}$ polymorphisms and RCC risk.

\section{MATERIAL AND METHODS}

\section{Subjects}

A hospital-based case-control design was used in this study. The case group is composed of 274 patients with RCC who were referred to Huaihe Hospital of Henan University between May 2013 and January 2015, being newly diagnosed and confirmed as having RCC by the presence of pathological tissue. Patients with a history of malignant tumors other than RCC, serious chronic and acute infection diseases, and serious kidney and liver diseases were excluded. The mean age of patients with RCC was $52.45 \pm 8.50$ years, and patients were comprised of $191(69.71 \%)$ males and 83 (30.29\%) females. There were $200(72.99 \%)$ patients at I-II TNM stage and $74(27.01 \%)$ patients at III-IV stage.

A total of 274 cancer-free control subjects were enrolled individuals attending our hospital between May 2013 and January 2015. Each control subject was sex- and age-matched 
( \pm 5 years) with each RCC patient. The mean age of patients with RCC was $53.70 \pm 9.12$ years, and patients were comprised of 191 males (69.71\%) and 83 females (30.29\%). All the lifestyle and clinical data of patients with RCC and control subjects were included from a structure questionnaire or medical records.

Each participant signed a written informed consent forms prior to enrollment. Institute Research Ethics Committee of Huaihe Hospital of Henan University approved the performance of this study.

\section{Genotyping}

Genomic DNA was isolated from $5 \mathrm{~mL}$ of peripheral blood lymphocytes using a Qiagen Blood Mini Kit (QIAGEN, Hilden, Germany). Genotyping determination of IL-16 rs4778889 T/C and rs11556218 T/G polymorphisms was done by polymerase chain reaction (PCR) combined with restriction fragment length polymorphism assay. The forward and reverse primers used to amplify rs4778889 T/C were 5'CTCCACACTCAAAGCCTTGTCCTATG-3' and 5'-ATACGCTGGTTCCACTTCT-3', while those for rs $11556218 \mathrm{~T} / \mathrm{G}$ were 5'-GCTCAGGTTCACAGAGTGTTTCCATA-3' and 5'-TGTGACAATCACAGCTTGCCTG-3', respectively. The PCR product sizes for $I L$ $16 \mathrm{rs} 4778889 \mathrm{~T} / \mathrm{C}$ and $\mathrm{rs} 11556218 \mathrm{~T} / \mathrm{G}$ were 171 and $280 \mathrm{bp}$, respectively. The restriction enzymes for $I L-16$ rs4778889 T/C and rs $11556218 \mathrm{~T} / \mathrm{G}$ were NdeI and AhdI, respectively. PCR amplification was set as follows: one cycle of DNA denaturation at $95^{\circ} \mathrm{C}$ for $5 \mathrm{~min}$, then 30 cycles of $94^{\circ} \mathrm{C}$ for $60 \mathrm{~s}, 55^{\circ} \mathrm{C}$ for $60 \mathrm{~s}$, and $72^{\circ} \mathrm{C}$ for $2 \mathrm{~min}$, followed by a final extension step of $72^{\circ} \mathrm{C}$ for $5 \mathrm{~min}$.

\section{Statistical analysis}

Differences in the demographic and clinical data were compared between the two groups by the chi-square test. A goodness of fit chi-square test with one degree of freedom was taken to assess the Hardy-Weinberg equilibrium (HWE) in the control group was assessed using. The relationship between $I L-16 \mathrm{rs} 4778889 \mathrm{~T} / \mathrm{C}$ and $\mathrm{rs} 11556218 \mathrm{~T} / \mathrm{G}$ polymorphisms and $\mathrm{RCC}$ risk was determined using conditional logistic regression analysis, and the results are expressed as odds ratios (ORs) and their 95\% confidence intervals $(95 \% \mathrm{CI})$. All statistical analysis was carried out by the SPSS statistical software package, version 16.0 (SPSS Inc., Chicago, IL, USA). Two-sided P-values less than 0.05 were considered statistically significant.

\section{RESULTS}

All the demographic and lifestyle characteristics of RCC patients and control subjects were collected prior to any treatment and were shown in Table 1 . The chi-square test revealed that a significant different was found between participants with RCC and controls in terms of hypertension (chi-square $=10.79, \mathrm{P}<0.001$ ) and diabetes (chi-square $=7.91, \mathrm{P}=0.005$ ). The RCC patients are comparable with the control subjects with respect to age, sex, cigarette smoking, alcohol consumption, or family history of cancer. In the RCC patients, $200(72.99 \%)$ exhibited TNM stages I-II, while 74 (27.01\%) were at stages III-IV. Clear cell RCC was seen in 229 cases $(83.58 \%)$. 
Table 1. Demographic and clinical characteristics of patients with RCC and control subjects.

\begin{tabular}{|c|c|c|c|c|c|c|}
\hline Characteristics & Cases & $\%$ & Controls & $\%$ & $\chi^{2}$ test & $\mathrm{P}$ value \\
\hline \multicolumn{7}{|l|}{ Age, years } \\
\hline$<60$ & 176 & 64.23 & 180 & 65.69 & & \\
\hline$\geq 60$ & 98 & 35.77 & 94 & 34.31 & 0.13 & 0.72 \\
\hline \multicolumn{7}{|l|}{ Sex } \\
\hline Male & 191 & 69.71 & 191 & 69.71 & & \\
\hline Female & 83 & 30.29 & 83 & 30.29 & 0.00 & 1.00 \\
\hline \multicolumn{7}{|c|}{ Cigarette smoking } \\
\hline Never & 162 & 59.12 & 174 & 63.50 & & \\
\hline Ever & 112 & 40.88 & 100 & 36.50 & 1.11 & 0.29 \\
\hline \multicolumn{7}{|l|}{ Alcohol drinking } \\
\hline Never & 145 & 52.92 & 155 & 56.57 & & \\
\hline Ever & 129 & 47.08 & 119 & 43.43 & 0.74 & 0.39 \\
\hline \multicolumn{7}{|l|}{ Hypertension } \\
\hline No & 184 & 67.15 & 218 & 79.56 & & \\
\hline Yes & 90 & 32.85 & 56 & 20.44 & 10.79 & 0.001 \\
\hline \multicolumn{7}{|l|}{ Diabetes } \\
\hline No & 232 & 84.67 & 253 & 92.34 & & \\
\hline Yes & 42 & 15.33 & 21 & 7.66 & 7.91 & 0.005 \\
\hline \multicolumn{7}{|c|}{ Family history of cancer } \\
\hline Never & 251 & 91.61 & 257 & 93.80 & & \\
\hline Ever & 23 & 8.39 & 17 & 6.20 & 0.97 & 0.32 \\
\hline \multicolumn{7}{|l|}{ Stage } \\
\hline I-II & 200 & 72.99 & & & & \\
\hline III-IV & 74 & 27.01 & & & & \\
\hline \multicolumn{7}{|l|}{ Histology } \\
\hline Clear cell & 229 & 83.58 & & & & \\
\hline Papillary & 10 & 3.65 & & & & \\
\hline Chromophobe & 22 & 8.03 & & & & \\
\hline Others & 13 & 4.74 & & & & \\
\hline
\end{tabular}

The analysis revealed that the genotype frequencies of rs $4778889 \mathrm{~T} / \mathrm{C}$ and $\mathrm{rs} 11556218$ $\mathrm{T} / \mathrm{G}$ did not deviate from HWE, with P values of 0.34 and 0.22 , respectively (Table 2). We observed significant differences in rs4778889 genotype frequencies between the study groups (chi-square $=15.22, \mathrm{P}<0.001$ ). Compared to the TT genotype, the TC and CC genotypes of rs4778889 exhibited a higher risk of RCC, with adjusted ORs (and 95\%CIs) of 1.79 (1.232.62 ) and 2.67 (1.29-5.69), respectively. In addition, under both dominant and recessive models, individuals carried the rs4778889 polymorphism was exhibited elevated RCC risk, the adjusted ORs (and 95\%CIs) being 1.93 (1.35-2.76) and 2.11 (1.05-4.45), respectively. However, no significant differences were observed in rs11556218 genotype frequencies between the study groups.

The gene-environmental analysis was carried out to assess the effects of sex, age, hypertension, and diabetes on the relationship between rs4778889 and RCC risk. We found that the rs 4778889 was correlated with the susceptibility to the risk of this disease regardless of these factors. Therefore, this SNP demonstrated no interactions with sex, age, hypertension, or diabetes in influencing RCC risk (Table 3).

\section{DISCUSSION}

The incidence of RCC showed highly discrepancies in different ethnicities, which suggested that the genetic factors may contribute to the susceptibility to this disease. We carried out a study to evaluate the role of two important SNPs in the $I L-16$ gene, and their roles 
Table 2. Genotype frequencies of $I L-16$ rs4778889 T/C and rs $11556218 \mathrm{~T} / \mathrm{G}$ among the cases with RCC and controls and their association with risk of RCC.

\begin{tabular}{|c|c|c|c|c|c|c|c|c|c|}
\hline Genotypes & Patients & $\%$ & Controls & $\%$ & $\chi^{2}$ test & $P$ value & HWE & OR $(95 \% \mathrm{CI})^{1}$ & $P$ value \\
\hline \multicolumn{10}{|l|}{ rs4778889 } \\
\hline \multicolumn{10}{|l|}{ Codminant } \\
\hline TT & 132 & 48.18 & 176 & 64.23 & & & & 1.0 (Ref.) & - \\
\hline $\mathrm{TC}$ & 113 & 41.24 & 84 & 30.66 & & & & $1.79(1.23-2.62)$ & 0.002 \\
\hline $\mathrm{CC}$ & 28 & 10.22 & 14 & 5.11 & 15.22 & $<0.001$ & 0.34 & $2.67(1.29-5.69)$ & 0.004 \\
\hline \multicolumn{10}{|l|}{ Dominant } \\
\hline TT & 132 & 48.18 & 176 & 64.23 & & & & 1.0 (Ref.) & - \\
\hline $\mathrm{TC}+\mathrm{CC}$ & 142 & 51.82 & 98 & 35.77 & 14.35 & $<0.001$ & & $1.93(1.35-2.76)$ & $<0.001$ \\
\hline \multicolumn{10}{|l|}{ Recessive } \\
\hline $\mathrm{TT}+\mathrm{TC}$ & 246 & 89.78 & 260 & 94.89 & & & & 1.0 (Ref.) & - \\
\hline $\mathrm{CC}$ & 28 & 10.22 & 14 & 5.11 & 5.05 & 0.03 & & $2.11(1.05-4.45)$ & 0.02 \\
\hline \multicolumn{10}{|l|}{ rs11556218 } \\
\hline \multicolumn{10}{|l|}{ Codminant } \\
\hline TT & 149 & 54.38 & 155 & 56.57 & & & & 1.0 (Ref.) & - \\
\hline TG & 110 & 40.15 & 107 & 39.05 & & & & $1.07(0.74-1.54)$ & 0.71 \\
\hline GG & 15 & 5.47 & 12 & 4.38 & 0.49 & 0.78 & 0.22 & $1.30(0.55-3.15)$ & 0.51 \\
\hline \multicolumn{10}{|l|}{ Dominant } \\
\hline TT & 149 & 54.38 & 155 & 56.57 & & & & 1.0 (Ref.) & - \\
\hline $\mathrm{TG}+\mathrm{GG}$ & 125 & 45.62 & 119 & 43.43 & 0.27 & 0.61 & & $1.09(0.77-1.55)$ & 0.61 \\
\hline \multicolumn{10}{|l|}{ Recessive } \\
\hline $\mathrm{TT}+\mathrm{TG}$ & 259 & 94.53 & 262 & 95.62 & & & & 1.0 (Ref.) & - \\
\hline GG & 15 & 5.47 & 12 & 4.38 & 0.17 & 0.68 & & $1.26(0.54-3.02)$ & 0.55 \\
\hline
\end{tabular}

${ }^{1}$ Adjusted for gender, age, hypertension, and diabetes.

Table 3. Stratification analysis between IL16 rs4778889 T/C and risk of RCC by gender, age, hypertension, and diabetes.

\begin{tabular}{|c|c|c|c|c|c|c|}
\hline \multirow{2}{*}{ Characteristics } & \multicolumn{2}{|c|}{ Patients } & \multicolumn{2}{|c|}{ Controls } & \multirow{2}{*}{ OR $(95 \% \mathrm{CI})$} & \multirow{2}{*}{ P value } \\
\hline & TT & $\mathrm{TC}+\mathrm{CC}$ & TT & $\mathrm{TC}+\mathrm{CC}$ & & \\
\hline \multicolumn{7}{|l|}{ Age, years } \\
\hline$<60$ & 84 & 92 & 114 & 66 & $1.89(1.21-2.96)$ & $<0.001$ \\
\hline$\geq 60$ & 48 & 50 & 62 & 32 & $2.02(1.08-3.77)$ & 0.02 \\
\hline \multicolumn{7}{|l|}{ Sex } \\
\hline Male & 90 & 101 & 118 & 73 & $1.81(1.18-2.78)$ & 0.004 \\
\hline Female & 42 & 41 & 58 & 25 & $2.26(1.14-4.51)$ & 0.01 \\
\hline \multicolumn{7}{|l|}{ Hypertension } \\
\hline No & 88 & 96 & 137 & 81 & $1.85(1.21-2.80)$ & 0.003 \\
\hline Yes & 44 & 46 & 39 & 17 & $2.40(1.13-5.19)$ & 0.01 \\
\hline \multicolumn{7}{|l|}{ Diabetes } \\
\hline No & 118 & 114 & 162 & 91 & $1.72(1.18-2.52)$ & $<0.001$ \\
\hline Yes & 14 & 28 & 14 & 7 & $4.00(1.16-14.30)$ & $<0.001$ \\
\hline
\end{tabular}

in the development of RCC. The results of this study suggest that the TC and CC genotypes of rs4778889 were associated with increased risk of RCC compared to the TT genotype, and revealed that this polymorphism was connected to elevated risk under dominant and recessive genetic models, even after adjusting for age, sex and other confounding factors. $I L-16$ is a multifunctional cytokine in pathophysiology of inflammatory diseases, as well as in tumor growth and progression. Previous studies have reported that genetic variation of $I L-16$ are associated with susceptibility to various inflammatory diseases, such as late-onset Alzheimer's disease, graves' disease, coronary artery disease and asthma and allergic rhinitis (Reich et al., 2003; Afifi et al., 2004; Hosseini-Farahabadi et al., 2007; Wu et al., 2011; Tsai et al., 2014; Anvar et al., 2015). Afifi et al. (2004) carried out a case-control study in An Egyptian population, finding that the IL-16 may be considered as a marker of severity of airway inflammation. Wu et al. (2011) conducted a study of 157 patients with CAD and 202 healthy controls, and reported that IL-16 genetic variation may be used as a genetic marker for CAD 
susceptibility. Tsai et al. (2014) conducted a further investigation involving 474 CAD patients with graves' disease, and reported that polymorphisms in IL-16 may be as genetic markers for the diagnosis of graves' disease. Anvar et al. (2015) carried out a study consisted of 144 patients with late-onset Alzheimer's disease and 173 healthy individuals, suggesting that IL16 genetic polymorphisms may play a protective role in the progression of Alzeimer's disease. Previous studies have reported that IL-16 genetic variation could influence the development of several kinds of cancer, such as nasopharyngeal cancer, renal cell cancer, hepatocellular cancer, colorectal cancer, glioma cancer and gastric cancer (Gao et al., 2009a,b; Obara, 2010; Li et al., 2011; Azimzadeh et al., 2011; Zhang and Wang, 2013; Luo et al., 2014; Qin et al., 2014). The abovementioned studies reveal that $I L-16$ gene polymorphisms are associated with cancer development.

SNPs in the IL-16 genes could alter gene expression, structure, as well as the level of proteins produced, which in turn affects gene function. Currently, only one previous study reported the role of $I L-16$ polymorphism in RCC susceptibility in a Chinese population (Zhu et al., 2010). This study conducted a case-control study involving 335 RCC patients and 340 cancer-free controls, and reported that IL-16 -295T $>$ C polymorphism is significantly associated with a higher risk of developing RCC in Chinese population. However, none have documented the relationship between the rs $4778889 \mathrm{~T} / \mathrm{C}$ and rs $11556218 \mathrm{~T} / \mathrm{G}$ SNPs and RCC occurrence. In our study, we firstly reported that $I L-16$ rs 4778889 gene polymorphism was correlated with the RCC risk. Therefore, further studies are greatly required to verify our findings.

In summary, we reveal that the $I L-16$ rs 4778889 polymorphism was correlated with elevated risk of RCC. Our investigation offers insights into the influence of $I L-16$ on the occurrence of this disease.

\section{Conflicts of interest}

The authors declare no conflict of interest.

\section{ACKNOWLEDGMENTS}

We thanks for the help from staffs who work in the Huaihe Hospital of Henan University for collecting the blood samples from patients.

\section{REFERENCES}

Adams KF, Leitzmann MF, Albanes D, Kipnis V, et al. (2008). Body size and renal cell cancer incidence in a large US cohort study. Am. J. Epidemiol. 168: 268-277.

Afifi SS, ElArab AE and Mostafa SY (2004). Interleukin 16 (IL-16) in asthma and allergic rhinitis. A comparison between upper and lower airways. Egypt. J. Immunol. 11:31-36.

Anvar NE, Saliminejad K, Ohadi M, Kamali K, et al. (2015). Association between polymorphisms in Interleukin-16 gene and risk of late-onset Alzheimer's disease. J. Neurol. Sci. 358: 324-327. http://dx.doi.org/10.1016/j.jns.2015.09.344

Azimzadeh P, Romani S, Mohebbi SR, Kazemian S, et al. (2011). Interleukin-16 (IL-16) gene polymorphisms in Iranian patients with colorectal cancer. J. Gastrointestin. Liver Dis. 20: 371-376.

Bellocco R, Pasquali E, Rota M, Bagnardi V, et al. (2012). Alcohol drinking and risk of renal cell carcinoma: results of a meta-analysis. Ann. Oncol. 23: 2235-2244. http://dx.doi.org/10.1093/annonc/mds022

Chow WH, Dong LM and Devesa SS (2010). Epidemiology and risk factors for kidney cancer. Nat. Rev. Urol. 7: 245-257. http://dx.doi.org/10.1038/nrurol.2010.46

Diekstra MH, Swen JJ, Boven E, Castellano D, et al. (2015). CYP3A5 and ABCB1 polymorphisms as predictors for sunitinib 
outcome in metastatic renal cell carcinoma. Eur. Urol. 68: 621-629. http://dx.doi.org/10.1016/j.eururo.2015.04.018

Gan XL, Lin YH, Zhang Y, Yu TH, et al. (2010). Association of an interleukin-16 gene polymorphism with the risk and pain phenotype of endometriosis. DNA Cell Biol. 29: 663-667. http://dx.doi.org/10.1089/dna.2010.1049

Gao LB, Rao L, Wang YY, Liang WB, et al. (2009a). The association of interleukin-16 polymorphisms with IL-16 serum levels and risk of colorectal and gastric cancer. Carcinogenesis 30: 295-299. http://dx.doi.org/10.1093/carcin/bgn281

Gao LB, Liang WB, Xue H, Rao L, et al. (2009b). Genetic polymorphism of interleukin-16 and risk of nasopharyngeal carcinoma. Clin. Chim. Acta 409: 132-135. http://dx.doi.org/10.1016/j.cca.2009.09.017

Hosseini-Farahabadi S, Tavakkol-Afshari J, Rafatpanah H, Farid Hosseini R, et al. (2007). Association between the polymorphisms of IL-4 gene promoter $(-590 \mathrm{C}>\mathrm{T})$, IL-13 coding region (R130Q) and IL-16 gene promoter $(-295 \mathrm{~T}>\mathrm{C})$ and allergic asthma. Iran. J. Allergy Asthma Immunol. 6: 9-14.

Huang Z, Lu Z, Tian J, Wang G, et al. (2015). Effect of a functional polymorphism in the pre-miR-146a gene on the risk and prognosis of renal cell carcinoma. Mol. Med. Rep. 12: 6997-7004.

Li S, Deng Y, Chen ZP, Huang S, et al. (2011). Genetic polymorphism of interleukin-16 influences susceptibility to HBV-related hepatocellular carcinoma in a Chinese population. Infect. Genet. Evol. 11: 2083-2088. http://dx.doi. org/10.1016/j.meegid.2011.09.025

Luo QS, Wang JL, Deng YY, Huang HD, et al. (2014). Interleukin-16 polymorphism is associated with an increased risk of glioma. Genet. Test. Mol. Biomarkers 18: 711-714. http://dx.doi.org/10.1089/gtmb.2014.0170

Luo SX, Li S, Zhang XH, Zhang JJ, et al. (2015). Genetic polymorphisms of interleukin-16 and risk of knee osteoarthritis. PLoS One 10: e0123442. http://dx.doi.org/10.1371/journal.pone.0123442

Muc-Wierzgon M, Nowakowska-Zajdel E, Kokot T, Kozowicz A, et al. (2006). Genetic disregulation of TNF alpha and TNF alpha type II receptors in colon cancer at the II and III stage of disease. J. Biol. Regul. Homeost. Agents 20: $10-14$.

Obara W (2010). Editorial comment to IL-16 polymorphism and risk of renal cell carcinoma: association in a Chinese population. Int. J. Urol. 17: 707. http://dx.doi.org/10.1111/j.1442-2042.2010.02583.x

Qin X, Peng Q, Lao X, Chen Z, et al. (2014). The association of interleukin-16 gene polymorphisms with IL-16 serum levels and risk of nasopharyngeal carcinoma in a Chinese population. Tumour Biol. 35: 1917-1924. http://dx.doi. org/10.1007/s13277-013-1257-2

Reich K, Westphal G, König IR, Mössner R, et al. (2003). Association of allergic contact dermatitis with a promoter polymorphism in the IL16 gene. J. Allergy Clin. Immunol. 112: 1191-1194. http://dx.doi.org/10.1016/j. jaci.2003.09.012

Semenza JC, Ziogas A, Largent J, Peel D, et al. (2001). Gene-environment interactions in renal cell carcinoma. Am. J. Epidemiol. 153: 851-859. http://dx.doi.org/10.1093/aje/153.9.851

Shanmugham LN, Petrarca C, Frydas S, Donelan J, et al. (2006). IL-15 an immunoregulatory and anti-cancer cytokine. Recent advances. J. Exp. Clin. Cancer Res. 25: 529-536.

Tsai KH, Chang CY, Tsai FJ, Lin HJ, et al. (2014). Association of interleukin-16 polymorphisms with graves' disease in a Taiwanese population. Chin. J. Physiol. 57: 69-75. http://dx.doi.org/10.4077/CJP.2014.BAB150

Vineis P, Alavanja M, Buffler P, Fontham E, et al. (2004). Tobacco and cancer: recent epidemiological evidence. J. Natl. Cancer Inst. 96: 99-106. http://dx.doi.org/10.1093/jnci/djh014

Wu J, Wang Y, Zhang Y and Li L (2011). Association between interleukin-16 polymorphisms and risk of coronary artery disease. DNA Cell Biol. 30: 305-308. http://dx.doi.org/10.1089/dna.2010.1145

Xian W, Zheng $\mathrm{H}$ and Wu WJ (2015). Predictive value of vascular endothelial growth factor polymorphisms on the risk of renal cell carcinomas. Genet. Mol. Res. 14: 7634-7642. http://dx.doi.org/10.4238/2015.July.13.8

Zhang T and Wang H (2013). Variants of interleukin-16 associated with gastric cancer risk. Asian Pac. J. Cancer Prev. 14: 5269-5273. http://dx.doi.org/10.7314/APJCP.2013.14.9.5269

Zhu J, Qin C, Yan F, Wang M, et al. (2010). IL-16 polymorphism and risk of renal cell carcinoma: association in a Chinese population. Int. J. Urol. 17: 700-707. http://dx.doi.org/10.1111/j.1442-2042.2010.02559.x 